\title{
【特集II】〈第25回日本外科系連合学会学術集会ビデオシンボジウム2〉 甲状腺・乳腺・副腎の内視鏡下手術
}

\author{
4 。腹腔鏡下副腎摘除術一経腹腔到達法および腹膜外到達法一
}

\author{
浜松医科大学泌尿器科 \\ 鈴 木 和 雄
}

\section{Laparoscopic Adrenalectomy - Transperitoneal and Extraperitoneal Approaches-}

\author{
Kazuo SUZUKI
}

Department of Urology, Hamamatsu University School of Medicine

経腹腔到達法および腹膜外到達法による腹腔鏡下副腎摘除術の手術手技について概説した。経腹腔到達法の場 合，体位を側臥位とし，腹膜を大きく切開して腹腔内臟器を下方（正中側）に受動し，大きな視野を得ることが ポイントである。すなわち, 右側では肝・結腸間膜を切開し, この切開線を肝右葉に沿って延長し, 肝三角靶帯 の一部を切開して肝を正中側に圧排する。左側では, 横隔膜・結腸靶帯を切開した後, 腹膜切開線を脾の外側に 沿って胃大弯側が見えるまで延長し，脾を自重により正中側に受動すれば良好な視野が得られる。

腹膜外到達法の場合は, 後腎傍腔をバルンなどで充分拡張した後, 脂肪 (flank pad) を除去し, 円錐外側筋膜 および腹膜を正中側に剝離し，広い操作腔を作成する必要がある。

いずれの到達法においても, 副腎の剥離は副腎周囲から開始し, 横隔膜, 腸腰筋, 腹横筋, 腰方形筋を剥離面 の指標とする。上副腎血管を処理した後, 副腎を周囲脂肪組織と一塊として遊離し, 最後に副腎静脈を切断する。 腹腔鏡下手術に馴れないうちは瘦せた症例を選ぶこと, 静脈の走向を念頭にいれた慎重な剝離操作などが要求さ れる。手術が困難と思われたら，深追いせず，速やかに開腹手術に移行する姿勢が肝要である。

索引用語 : 腹腔鏡下手術(laparoscopic surgery), 副腎摘除術 (adrenalectomy), 経腹腔到達法(transperitoneal approach)，腹膜外到達法 (extraperitoneal approach)

\section{はじめに}

近年，腹腔鏡下副腎摘除術は，5～6 cm以下の 良性副腎腫瘍に対する標準術式になったと言って も過言ではない。本稿では, 経腹腔到達法および 腹膜外到達法による副腎摘除術の手技の実際，手 術のコツについて述べる。

\section{経腹腔到達法による腹腔鏡下副腎摘除術 ${ }^{12)}$}

\section{1 , 左副腎摘除術}

1）体位・トロカー留置

体位はジャックナイフをかけた完全側臥位とす る。鎖骨中線上，胁骨弓やや下方に約 $2 \mathrm{~cm}$ の皮膚
切開をおき, open methodで10mmトロカーを留 置する。12mmHgの圧で気腹後, 腹腔鏡を挿入し 腹腔内を観察する。腹腔鏡監視下に正中線上やや 左側, 胸骨突起から約 $5 \mathrm{~cm}$ 尾側に $5 \mathrm{~mm}$ 卜ロカ 一, 前腋窩線上, 胁骨弓下に $5 \mathrm{~mm}$ トロカー, 後腋 窩線上, 肋骨弓下に $5 \mathrm{~mm}$ 卜ロカーを留置する。術 者は患者の腹側に立ち, 正中線上のトロカーから 把持鉗子を，前腋窩線上のトロカーから超音波駆 動メス (LCS) や注水・吸引・電気メスプローベ などを挿入し剝離操作を行う（Fig. 1a）。

2 ）副腎の剝離

まず，横隔膜・結腸靶帯を切開し，腹膜，腎筋 


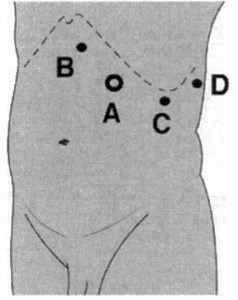

a

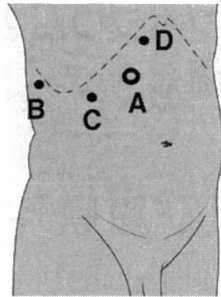

b

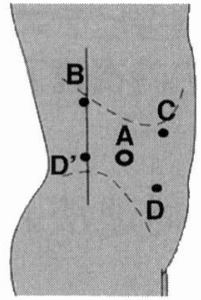

c
Fig: 1 Trocar positions.

A : 10-mm trocar for the laparoscope. B and C : 5 -mm trocars for the surgeon.

D or $D^{\prime}: 5-m m$ trocars for the assistant.

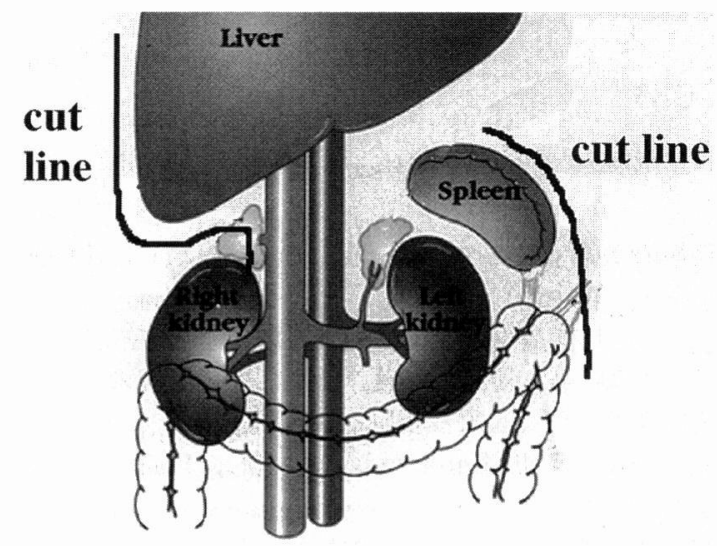

Fig. 2 Cut line of the peritoneal membrane.

膜の切開を脾臓の外側に沿って頭側に延長し，胃 の大弯側が見える部まで切開する(Fig. 2$)$ 。膵後 面が露出するまで，脾藏を脱転するように正中側 に十分受動する。これらの剝離操作で副腎は術野 の正面に展開される。必要に応じて, 腹膜, 粲筋 膜の切開を尾側に延長する。副腎の剝離はまず上 極から開始する。脾臟外側, 上方で横隔膜を露出 し, 横隔膜に沿って副腎上極の脂肪を剥離し, 順 次外側, 内側に剝離を進める。副腎上，内側で下 横隔静脈に流入する上副腎静脈を露出し, クリッ プをかけ切断する。副腎の内側は膵後面との間を, 外側は腰方形筋との間を剝離する。剝離の際は周 囲の脂肪とともに副腎を一塊として剥離する。次 に腎上極と副腎の間をLCSにて剥離する。この部 には下副腎動静脈, 後副腎静脈などがあるが, LCSで切離すれば出血はほとんどない。副腎全周 を剥離後, 副腎周囲の脂肪を把持し, 副腎を挙上
しつつ尾側，内側に剝離を進める。助手が後腋窩 線上のトロカ一から把持鉗子を挿入し，腎上極を 尾側に圧排または副腎を挙上すると視野がよくな るが, 助手の助けを必要としないことも多い。最 後に副腎静脈を露出し, クリップを $3 \sim 4$ 本かけ 切断する。

3 ）副腎の摘出, 閉創

完全に遊離した副腎は袋に収納し, 小切開創か ら一塊として摘出する。 $5-6 \mathrm{mmHg}$ の圧で再気 腹を行い, 術野を十分洗浄後, 出血の無いのを確 認する。腹腔鏡下監視下にトロカーを抜去し閉創 する。われわれは，切開した腹膜の縫合は行って いない。術後の肩放散痛を予防するため，炭酸が 又を十分脱気しておく。通常ドレンチューブは留 置しないが，炭酸ガス脱気の目的でペンロースド レンを一晚留置してもよい。

4 ）左腹腔鏡下副腎摘除術のコツ

腹膜，腎筋膜の切開を脾臓の外縁に沿って，胃 大弯部が見えるまで十分頭側に切り上げると, 脾 は自重により正中側に脱転し視野が非常によくな る。最初の剝離面として, 横隔膜を露出すること。 膵後面と副腎の間を剝離し, 上副腎静脈を注意深 く露出し切断すること。剝離は副腎周囲のやりや すい場所から徐々にLCSにて剥離すること,など が手術のコツである。

\section{2 ，右副腎摘除術}

1) 体位・卜ロカ一留置

体位は完全側臥位，トロカ一留置は左側と対称 に留置する(Fig. 1b)。術者が患者の腹側に立つ場 合は，肝圧排用のスネークヘッド鉗子を後腋窩線 上のトロカーから挿入する(Fig. 3left)。鉗子操作 に慣れてくれば，術者は患者の背側に立ち，後腋 窩線上と前腋窩線上のトロカーを使用し, 助手は 患者の腹側に立ち腹腔鏡と正中線上のトロカーか ら挿入したスネークヘッド鉗子を操作するように すれば術者が混み合わない（Fig. 3right）。

2 ) 副腎の剝離

まず，肝結腸間膜を切開し，切開線を肝に沿つ て外側から頭側に延長する (Fig. 2)。肝外側で横 隔膜を露出し, 横隔膜に沿って肝を剥離。肝三角 靱带の一部を切開し肝右葉を正中側に受動する。 肝と副腎上極との間を剥離し，さらに肝三角靱帯 

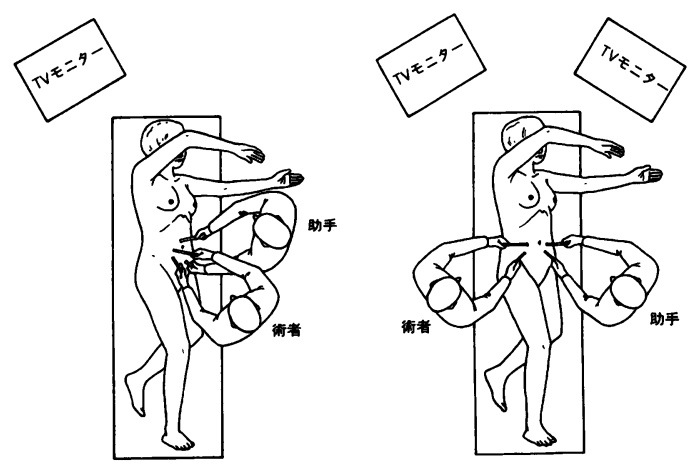

Fig. 3 Position of the surgeon and the instruments.

を切開し，十分肝を内側に移動すれば下大静脈近 くまで肝は内側に圧排され，広い視野を得ること が出来る。副腎の上方, 内側で上副腎血管を露出 し，クリップをかけ切断する。副腎上極が肝下面 に嵌入している場合や，強い癒着がある場合は無 理をせず，副腎外側の剥離に移行し，副腎上極の 剝離は最後に行うことになる。副腎上, 外側で横 隔膜に沿って副腎周囲脂肪組織を剝離する。次に 腎上極と副腎の間をLCSで切離する。副腎下極で 下・後副腎血管を処理した後, 下大静脈を慎重に 剝離し, 副腎の腹側から出て, 下大静脈に直接流 入する副腎静脈を露出する。副腎を軽く外側に牽 引しながら副腎静脈を慎重に剝離し，クリップを $3 \sim 4$ 本かけ切断する。副腎静脈を切断後, 下大 静脈に沿って頭側に向かい剥離を進め, 上副腎血 管，副腎上極を処理する。

3 ) 副腎の摘出, 閉創

左側と同様である。

4 ) 右腹腔鏡下副腎摘除術のコツ

肝・結腸間膜の切開を肝外側に延ばし, 副腎の 上方, 外側で横隔膜を露出し, この横隔膜を剥離 面の指標として, 副腎周囲の剥離を進める。特に 腫瘍が大きい場合は, 肝三角靶帯を切開し, 肝を 十分内側に受動することが必要である。右副腎静 脈は短く，直接下大静脈から分岐している。短肝 静脈の高さを目安にして, 副腎静脈を慎重に同定, 剝離する。

\section{腹膜外到達法による腹腔鏡下副堅摘除術3)45)}

\section{1. 体位・トロカー留置}

体位は側臥位とし，ジャックナイフをかけ患側
側腹部を進展させる。第 1 トロッカーは, 中腋窩 線上で腸骨稜やや上に約 $2 \mathrm{~cm}$ の皮膚切開をおき, 用手的およびバルーンで後腹膜腔を拡張した後, バルントロカーを挿入する。第 1 トロッカーは, 内視鏡用とする。第 2 トロッカーは後腋窩線上で 肋骨弓直下に穿刺する。このトロッカーから鉗子 を挿入し, 腹膜, 円錐外側筋膜を十分内側に剝離

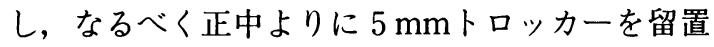
する(Fig. 1c)。腹膜を腹壁から剥離する場合, 頭 側は横隔膜近くまで，尾側は腸骨血管分岐部近く まで十分剥離すれば，腹膜は腸管などとともに下 方に受動され，十分な術野を得ることが出来る。 また, Gerota筋膜外側にある後腎傍腔の脂肪組織 (flank pad)を十分剥離し，尾側に排除しておく と, 視野がよくなる。Flank padの剝離の際, 腹壁 から脂肪組織に入る数本の血管があるので出血に 注意する。

\section{2. 副腎の剥離}

Gerota筋膜をきれいに露出した後, 上下に大き く切開し, 腎, 副腎を含む腎周囲脂肪織を露出す る。Gerota筋膜の切開はなるべく背側で腹斜筋に 沿って行い, 頭側は横隔膜起始部まで十分切開す る。腹側で切開すると腹膜を開いてしまう可能性 がある。腹膜を切開した場合, 腹膜を大きく開空 すれば術野はあまり影響されない。

腹膜外到達法の場合, 特に肥満例では腎周囲脂 肪組織に埋もれた副腎をいかに同定するかが問題 である。Gerota筋膜を大きく切開したら，まず初 めに副腎, 腎上極を脂肪組織とともに, 外側は腹 斜筋, 腰方形筋, 腸腰筋, 上方は横隔膜, 内側は 腹膜・肝下面 (右) ・膵 (左) との間で剥離してい く。これらの剥離操作で, 脂肪に包まれた副腎, 腎上極はGerota筋膜内で一塊として浮き上がっ てくる。一塊となった副腎後面を内側に向かい十 分剥離すれば, 下大静脈 (右), 大動脈 (左) が露 出される。また, 副腎の上内側の剥離操作中に上 副腎静脈が露出されるので, クリップをかけ切断 する。ときに, 腰方形筋・腸腰筋から太い血管が 副腎に入っていることがあるので注意する。

腎上極，副腎を脂肪とともに一塊として剥離し た後，鉗子などで脂肪組織を大きく把持したり， 押したりして，腎上極と副腎の間の見当をつけ， 
この部の脂肪をLCSにて切開する。腎上極を露出 した後，腎の表面を剥離面の指標として副腎との 間を剝離していく。副腎につけた余分な脂肪組織 は，視野の妨げになるようならその都度摘除する ようにする。腎との間を剥離した後，脂肪ととも に副腎を挙上し，副腎下方から内側に向かい剥離 を進める。この部は，下・後副腎動静脈などの小 血管が多いのでLCSまたはバイポラー電気凝固 鉗子を用いて剥離する。右側では下・後副腎動静 脈を処理した後, 下大静脈を慎重に露出する。下 大静脈を頭側に向かい剥離し, 副腎静脈を慎重に 剥離する。右副腎静脈はあまり強く外側に牽引せ ず，下大静脈，副腎静脈を慎重に露出してからク リップをかけ切断する。左側では, 副腎のほぼ全 周を剥離した後, 副腎の下方, 内側で副腎静脈を 露出する。静脈にクリップを $3-4$ 本かけ切断す る。

神経節神経腫などの特殊な腫瘍を除き，副腎腫 瘍は被膜が薄く, 脆弱なため, 容易に破損する。 鉗子などで腫瘍を直接把持しないことが肝要であ る。正常副腎組織も極力把持せず，周囲組織を垷 んで挙上するようにする。やむなく正常副腎を掴 む場合は，平坦な大きな鉗子でごく軽く掴むよう にする。

比較的大きな腫瘍では, 時に上副腎静脈が発達 しており，これを損傷すると思わぬ大量出血をき たすことがある。副腎の上内側を剝離するときは, この上副腎静脈の存在を常に念頭に置いて, 慎重 に剝離し，クリップをかけ切断する。腹膜外到達 法は, 経腹腔到達法よりも炭酸がスの体内吸収が 多い。術中の呼吸管理, 術後の換気能に十分注意 する必要がある。クッシング症候群患者では，手 術数日前から呼吸訓練を十分行っておく必要があ る。

\section{3 、副腎の摘出, 閉創}

経腹腔到達法と同様である。通常, ドレンチュ ーブは留置しない。

\section{4 、腹膜外到達法による腹腔鏡下副腎摘除術のコ ッ}

後腹膜腔の拡張は必ずGerota筋膜外側で行う。 後腎傍腔の脂肪組織を丁寧に除去すれば, Gerota
筋膜が明瞭に露出される。瘦せた症例では, Gerota筋膜を開いた時点で腎上方に副腎を同定出来 ることもあるが，肥満例では副腎は腎上極ととも に脂肪に完全に被われており，副腎を見つけだす のは容易なことではない。豊富な脂肪をかき分け ながら直接副腎を探しにいくと, 出血により視野 は悪くなり, 脂肪が邪魔をし，オリエンテーショ ンも付かなくなり，いよいよ手術は泥沼に陥るこ とになる。副腎を直接探しに行かず, 周囲から攻 め込むことが本術式のコツである。

\section{おわりに}

経腹腔および腹膜外到達法による腹腔鏡下副腎 摘除術の手技について概説した。経腹腔到達法は 術野が広く, 周囲臟器の同定も容易であり, 脾, 肝, 結腸を内側に十分圧排すれば副腎の剝離操作 は容易である。一方, 腹膜外到達法は経腹腔到達 法に比べて手技的にやや難易度が高いものの, 術 後の回復が早く, 肩放散痛, 麻痺性イレウス, 腸 管癒着が回避でき，より低侵襲手術と言える。術 者が腹腔鏡下副腎摘除術に不慣れな場合や, 腫瘍 径が $5 \mathrm{~cm}$ を越える場合は経腹腔到達法が適して いる。一方, 術者が腹腔鏡下手術に習熟しており, 腫瘍が比較的小さい場合は腹膜外到達法が適して いる。いずれにせよ, 患者, 腫瘍の状態, 術者の 技量に応じて最も適した術式を選択することが, 合併症を回避するポイントである。

\section{参考文献}

1）鈴木和雄：副腎摘除術一経腹膜到達法. 泌尿器科 腹腔鏡手術. 松田公志編, メディカルビュー社, 東京, $2000, \mathrm{p} 40-45$

2）鈴木和雄: 腹腔鏡下副腎摘除術一褐色細胞腫の 剥離法。日内視鏡外会誌 $5 ： 196-199,2000$

3）鈴木和雄, 牛山知已：後腹膜手術の基本手技. 泌 尿器科腹腔鏡手術. 松田公志編, メディカルビュ 一社, 東京, 2000, p24-29

4）鈴木和雄：内視鏡下副腎摘除（経後腹膜腔） 1 , 側方アプローチ. 内分泌外科の要点と盲点. 幕内 雅敏, 小原孝男編, 文光堂, 東京, 1999, p200-203

5) Suzuki K: Laparoscopic adrenalectomy : retroperitoneal approach. Urol Clin North Am $28: 85-95,2001$ 